\title{
Italian Zeolitites in the Control of Grey Mould and Sour Rot and Their Effect on Leaf Reflectance, Grape and Wine
}

\author{
Francesco Calzarano $^{1, *(\mathbb{D})}$, Leonardo Seghetti ${ }^{2}$, Giancarlo Pagnani ${ }^{1}$ (D) and Stefano Di Marco ${ }^{3}$ \\ 1 Faculty of Bioscience and Technologies for Food, Agriculture and Environment, University of Teramo, \\ Via Renato Balzarini, 1, 64100 Teramo, Italy; gpagnani@unite.it \\ 2 IIS “C. Ulpiani”, Via della Repubblica 30, 63100 Ascoli Piceno, Italy; leonardo.seghetti@tin.it \\ 3 CNR, IBE, Via Gobetti 101, 40129 Bologna, Italy; stefano.dimarco@ibe.cnr.it \\ * Correspondence: fcalzarano@unite.it
}

Received: 23 October 2020; Accepted: 23 November 2020; Published: 25 November 2020

\begin{abstract}
The activity of two zeolitites, differing in the presence of copper and their particle size, was assessed in a Trebbiano d'Abruzzo white berry cultivar, towards grapevine grey mould and sour rot, a serious problem in almost all grapevine-growing areas. In 2018 and 2019, zeolitites were applied before forecast of rainfalls, which likely induce infection. In 2019, further applications were carried out 10 or 2 days before harvest, regardless of the rainfall, in order to verify the effect of the zeolitite residue on leaf reflectance and composition of grapes and wines. Both zeolitites significantly reduced the infections. Only the vines treated 2 days before harvest, especially with copper zeolitite, showed a decrease in leaf reflectance. However, no differences in the yield composition related to the time of zeolitite application, as well as a decrease of yield quality, were ever recorded. Furthermore, analysis of samples collected from vines treated with zeolitites showed increases in grape soluble solids and in wine alcohol content. Our results suggest the use of zeolitites against grapevine rots as a possible effective alternative to the application of synthetic fungicides in the development of environmentally friendly control strategies.
\end{abstract}

Keywords: grey mould; sour rot; grapevine; NDVI; GNDVI; grapes; wines

\section{Introduction}

Grey mould caused by Botrytis cinerea (= Botryotinia fuckeliana; [1]) and grapevine sour rot caused by a complex of filamentous fungi, saprophytic yeasts, and bacteria [2] are two important diseases of the grapevine, widespread in all grapevine-growing areas. The severity of these diseases is linked to rainfall and humidity conditions and increases during ripening, when an effective control is required in order to reduce yield losses and/or significant decreases in grape quality [3,4].

In Italy, the control strategy against grey mould relies on a preventive treatment at pre-bunch closure followed by one or two treatments during the ripening, depending on rainfall occurrence. Different synthetic fungicides are normally used in an integrated management, but with restrictions directed to both avoid the occurrence of B. cinerea-resistant strains and reduce their impact on the environment and on the yield. Biological control agents, resistance inducers and natural fungicides, as well as rock flours, such as zeolitites [5], are used in organic viticulture and are characterized by a greater flexibility of use, due to the general lack of undesirable effects. Moreover, biological and natural products can also be used in integrated control strategies, alternately with chemical treatments, thus reducing their use.

The control of sour rot is not always effective, because it is based on the side effects of fungicides used for the control of grey mould [6]. The use of preventive measures is also recommended, such as the 
choice of less sensitive cultivars, avoiding those with compact clusters [7], and the adoption of practices to reduce the occurrence of lesions in berries, caused by powdery mildew and/or Lobesia botrana.

The severity of the disease increases with transmission by insects of the pathogens responsible for sour rot, in particular by Drosophila spp. [8].

The adoption of cultural practices aimed at reducing the probability of infection is therefore recommended for the control of both grey mould and sour rot. The main practices are rows oriented in the direction of the prevailing winds to favour canopy aeration, avoiding excessive nitrogen fertilization, and leaf removal at pre-flowering, which is very effective in the case of grey mould, by reducing up to $50 \%$ of damage $[9,10]$.

Zeolites are tectosilicates and include 52 different mineral species [11,12]. The crystal structure and cation-exchange capacity (ranging from 100 to $300 \mathrm{meq} / 100 \mathrm{~g}$ ), the hydration properties, and the adsorption capacity are well-known characteristics of zeolites, as reported by different studies [13,14]. The zeolitites, which are zeolites-rich rocks with a high content of pure zeolite $(>50 \%)$, have different areas of application [11].

In agriculture, zeolitites are mainly used to improve some characteristics of the soils associated with better absorption of water and nutrients $[15,16]$. Some beneficial effects of zeolite treatments on apple trees were also reported, showing in particular some increased photosynthesis, due to the ability of zeolitites to adsorb carbon dioxide [17].

On the other hand, zeolitites are little used to protect the plants from diseases and pests [18]. For the first time, the effectiveness of zeolitites in the control of grey mould, sour rot, and L. botrana on grapevine has been preliminarily demonstrated in central Italy [5].

Nevertheless, the use of zeolitites in grapevine control strategies may have undesirable side effects in red-berry cultivars. In particular, applications that are too close to harvesting can cause decreases in the polyphenols and colour intensity in wines [5]. On the contrary, in white grape cultivars, the effects of an application close to harvest could be different. Zeolitites can act as a clarifying agent similar to bentonite, favouring tartaric and protein stability [19].

Therefore, it cannot be excluded that zeolitite applications carried out to protect vineyards against pests and diseases may also have favourable effects in the winemaking process of white cultivars.

The objective of the present study was to provide further evidence on the activity of zeolitites against grey mould and sour rot in a grapevine white cultivar, comparing two different zeolitite-based products. Furthermore, in the vines treated with these products, the effects of the deposit on leaf reflectance, and grape and wine composition were also evaluated.

\section{Materials and Methods}

\subsection{Zeolitite Based Products}

The vineyard trials were carried out against grey mould and sour rot by comparing the activity of two formulations of Italian chabasite-rich zeolitites collected from quarries in Sorano (Grosseto), central Italy (Agrisana s.r.l.). Both zeolitites have a high content in chabasite, high values of cation exchange capacity (CEC) $(2.17 \mathrm{meq} / \mathrm{g})$, and water retention (48.5\% p/p) [20]. The zeolitites differed for the presence of fine-size particles, and of copper in one of the two formulations. Copper, as sulfate pentahydrate and hydroxide, was industrially incorporated in the crystal structure of the zeolitite, in order to increase its persistence of activity thanks to a better availability over time. This product has a copper concentration of $6 \%$ for a potential activity against downy mildew. The first zeolitite was named Italian chabasite-rich zeolitite (ICZ) [5], the second one Italian copper chabasite-rich zeolitite (ICZCu).

\subsection{Zeolitite Application and Disease Assessment}

The trials were carried out in a 42-year-old vineyard located in Controguerra (TE, central Italy), cv. Trebbiano d'Abruzzo on 420A rootstock, Geneva Double Curtain (GDC) as a training system 
and plants spaced $2 \mathrm{~m}$ inter and $4 \mathrm{~m}$ between the rows, respectively. The vineyard was planted on a clayey-calcareous soil, with an average yield per vine ranging from 13 to $16.5 \mathrm{~kg}$ of grapes.

The trials were carried out in 2018 and 2019. The vineyard had a slope of $15 \%$. Therefore, 3 blocks of the same size $\left(1144 \mathrm{~m}^{2}\right)$ were identified as the highest (called "Upper zone"), the median ("Central zone"), and the lowest ("Lower zone") part of the vineyard. For each treatment (ICZ, ICZCu, and untreated control), three replicates, one per block, were set up. In each block, a replicate comprised 4 plots, each consisting of 14 plants arranged in 2 rows, taking care to avoid that the same treatment plot was not adjacent (Table 1).

Table 1. Field application details towards grey mould and sour rot on cv. Trebbiano d'Abruzzo in Controguerra vineyard in 2018 and 2019.

\begin{tabular}{ccc}
\hline Treatment $^{\mathbf{1}}$ & Active Ingredients & $\begin{array}{c}\text { Dose } \\
\mathbf{( K g} / \mathbf{L ~ h a} \mathbf{~ h}^{-\mathbf{1})}\end{array}$ \\
\hline 1-ICZ & Italian chabasite-rich zeolitite & 15 \\
2-ICZCu & Italian copper chabasite-rich zeolitite & 4 \\
3-Untreated Control & $/$ & $/$ \\
\hline pplication date and BBCH growth stage: 16 July, 77; 9 August, 77; 18 August, 83; 1 September, 85. 2019 \\
ion date and BBCH growth stage: 6 July, 75; 26 July, 77; 21 August, 83; 1 September, 85.
\end{tabular}

12018 Application date and BBCH growth stage: 16 July, 77; 9 August, 77; 18 August, 83; 1 Septch
Application date and BBCH growth stage: 6 July, 75; 26 July, 77; 21 August, 83; 1 September, 85.

In both years of the trial, in order to assess the activity of zeolitite formulations, the plots were treated according to the growth stage and rainfall, except for the application at pre-bunch closure (BBCH 77), which was carried out regardless of the climatic conditions (Table 1, Tables S1 and S2). In consideration of the low effect of $B$. cinerea infections up to the end of flowering, no applications were carried out until the "Berries pea-sized" (BBCH 75).

The zeolitite applications were based on the weather forecasts and carried out in the days immediately preceding the rains likely to induce infections, given the persistence and resistance to wash-off of the formulations [5]. After the applications, rainfall, temperature, and wetting were recorded from pre-flowering to harvest in order to verify the conditions predisposing the infection (Tables S1 and S2).

Leaf removal at the bunch zone was performed at the "Berries pea-sized" growth stage (BBCH 75) in both years of trials.

Zeolitites, as a wettable powder, were uniformly applied on the whole canopy by an air blast sprayer in a water volume of $500 \mathrm{~L} \mathrm{ha}^{-1}$.

The assessments of activity against grey mould and sour rot were carried out on 12 September 2018 and on 8 September 2019. For each replicate of each treatment, 15 bunches were collected from plants located in the central position of each of the 4 plots in each of the 3 blocks. The percentage of infected bunches (incidence) and the percentage of infected berries (severity) were determined.

\subsection{Effect of the Zeolitite Residue on Leaf Reflectance and on Grape and Wine Composition}

In 2019, after the assessment of the activity towards grey mould and sour rot, ICZ and ICZCu were applied again. In each block, the applications were carried out on 9 September on 2 of the 4 plots of ICZ and ICZCu treatment, and on 17 September on the other two plots. Therefore, 5 treatments were considered by comparing ICZ-1 and ICZCu-1, associated with the application of 9 September; ICZ-2 and ICZCu-2, associated with the application of 17 September; and untreated control. Each treatment had 3 replicates, each represented by 2 plots in each of the three blocks. These additional zeolitite applications were carried out in order to assess the possible effect of zeolitite residue on the leaf reflectance, and on the composition of grapes and wines. Therefore, these applications were carried out regardless of the rainfall, which in turn did not occur until the harvest. 


\subsubsection{Leaf Reflectance}

Leaf reflectance measurements were carried out on September 19th by means of a portable spectroradiometer mod. Fieldspec Pro ${ }^{\circledR}$, Malvern Panalytical Ltd., Malvern, UK. For each block, in each of the two plots of each treatment, 3 plants were chosen from the central part of the plot. In each plant, 5 measurements of 5 leaves all exposed to the east and in full sun, for a total of 30 measurements per treatment, were carried out. The normalized difference vegetation index (NDVI) [21], and green normalized difference vegetation index (GNDVI) [22] were recorded. The trial compared the effect of zeolitite residue on leaf reflectance in the ICZ-1 and ICZCu-1 treatments in comparison with the ICZ-2 and ICZCu-2 treatments. ICZ-1 and ICZCu- 1 and ICZ-2 and ICZCu-2 were applied 10 and 2 days before the assessment, respectively.

\subsubsection{Grape and Wine Composition}

At harvest, 8 plants of each treatment (ICZ-1, ICZ-2, ICZCu-1, ICZCu-2, and untreated control) were considered from the central part of 2 plots of each treatment, in each of the 3 blocks. Therefore, each treatment included 3 replicates (one per block).

The yield of the 8 plants of each treatment was weighed in each block to evaluate the average yield per vine.

In each block, a sample of 120 berries ( 15 berries per plant) was collected from the 8 plants of each treatment. The berries came from the wings, tips, and centres of different bunches. These berry samples were analysed for soluble solids (Brix), $\mathrm{pH}$, and total acidity. Furthermore, the average weight of 30 berries and 30 grape seeds was determined (Table 2).

Table 2. Chemical analysis of Trebbiano d'Abruzzo berries and wines obtained from vines treated with Italian chabasite-rich zeolitite and Italian copper chabasite-rich zeolitite (ICZ and ICZCu) towards grey mould and sour rot in 2019 in Controguerra vineyard.

\begin{tabular}{cccc}
\hline Parameter & $\begin{array}{c}\text { Unit of } \\
\text { Measurement }\end{array}$ & Sample & Method of Analysis \\
\hline Malic acid & $\mathrm{g} \mathrm{L}^{-1}$ & Wines & Enzymatic \\
Tartaric acid & $\mathrm{g} \mathrm{L}^{-1}$ & Wines & Spectrophotometric \\
Total acidity & $\mathrm{g} \mathrm{L}^{-1}$ & Berries and wines & Acid/base titration \\
Soluble solids & $\circ \mathrm{Brix}$ & Berries & Fehling \\
$\mathrm{pH} 20^{\circ} \mathrm{C}$ & - & Berries and wines & Potentiometric \\
Ethyl alcohol & $\%$ vol. & Wines & Distillation \\
\hline
\end{tabular}

In each block, and for each treatment, a sample of $8 \mathrm{~kg}$ of grapes was collected $(1 \mathrm{~kg}$ per plant, from the wings, tips, and centres of clusters), and considered as a replicate. Immediately after harvesting, the stalks were manually removed from the berries. Then, the berries were crushed with a manual press. Must yield was standardized to $65 \%(w: v)$. In total, $20 \mathrm{~g} \mathrm{hL}^{-1}$ of commercial dry yeast (after rehydration) was added to the musts. Fermentation took place without the addition of $\mathrm{SO}_{2}$ and at a controlled temperature ranging from 18 to $20^{\circ} \mathrm{C}$.

After fermentation and decanting of the wine in 10-L glass demijohns, completed in 20 days, the wine was decanted again, and then bottled in $60.75-\mathrm{L}$ bottles to avoid problems during the ageing. After 8 months of in-bottle ageing, a 100- $\mathrm{mL}^{-1}$ aliquot was taken from each of the 6 bottles; the different aliquots were mixed to obtain a $600-\mathrm{mL}^{-1}$ sample for each of the 3 repetitions of each treatment. Each wine sample was analysed in accordance with the methods of the Official Gazette of the European Communities Regulation (EEC) No. 2676/90, Official Journal L 272, 3.10.1990 (Table 2) [23].

\subsection{Statistical Analysis}

Data related to (i) the activity of Italian chabasite-rich zeolitite (ICZ) and Italian copper chabasite-rich zeolitite (ICZCu) on grey mould and sour rot, (ii) the leaf reflectance of the plants treated 
with these products at different distances from the application, and (iii) the composition of grapes and wines were statistically analysed using Tukey's honest significant difference (HSD) test at $p=0.05$. Statistical analysis was performed using XLSTAT 2016 (Addinsoft, Paris, France).

\section{Results}

\subsection{Zeolitite Activity}

In Controguerra vineyard, the rainfall and leaf wetting period registered from pre-flowering to harvest maturity were $367 \mathrm{~mm}^{-1}$ and $281 \mathrm{~h}$ in 2018 and $202 \mathrm{~mm}^{-1}$ and $196 \mathrm{~h}$ in 2019, respectively (Tables S1 and S2). Despite these seasonal differences, the risk of infection assessed in these growth stages required four zeolitite applications in both years (Tables S1 and S2).

The infections showed different levels of incidence and severity depending on the annual rainfall, wetting period, and temperature, but the applications proved to be effective in both years (Tables S1 and S2 and Table 3).

Table 3. Activity of Italian chabasite-rich zeolitite and Italian copper chabasite-rich zeolitite (ICZ and ICZCu) towards grey mould and sour rot on Trebbiano d'Abruzzo vines of Controguerra vineyard.

\begin{tabular}{cccccc}
\hline \multirow{2}{*}{ Survey } & & \multicolumn{2}{c}{ Grey Mould } & \multicolumn{2}{c}{ Sour Rot } \\
\hline \multirow{2}{*}{ Treatment } & Incidence & Severity & Incidence & Severity \\
\hline \multirow{2}{*}{$12 / 09 / 2018$} & \multicolumn{2}{c}{$\%$} & \multicolumn{3}{c}{$\%$} \\
& 1-ICZ & $6.11 \mathrm{~b}$ & $0.19 \mathrm{~b}$ & $11.11 \mathrm{~b}$ & $0.38 \mathrm{~b}$ \\
& 2-ICZCu & $3.89 \mathrm{~b}$ & $0.08 \mathrm{~b}$ & $7.78 \mathrm{~b}$ & $0.33 \mathrm{~b}$ \\
& 3-Untreated Control & $23.89 \mathrm{a}$ & $2.61 \mathrm{a}$ & $40.00 \mathrm{a}$ & $3.86 \mathrm{a}$ \\
\hline $08 / 09 / 2019$ & 1-ICZ & $4.44 \mathrm{~b}$ & $0.06 \mathrm{~b}$ & $7.22 \mathrm{~b}$ & $0.19 \mathrm{~b}$ \\
& 2-ICZCu & $5.00 \mathrm{~b}$ & $0.08 \mathrm{~b}$ & $4.44 \mathrm{~b}$ & $0.19 \mathrm{~b}$ \\
& 3-Untreated Control & $16.11 \mathrm{a}$ & $0.91 \mathrm{a}$ & $28.33 \mathrm{a}$ & $1.50 \mathrm{a}$ \\
\hline
\end{tabular}

Incidence: percentage of infected bunches on the total number of bunches; Severity: percentage of infected berries on the total number of berries. Statistical analyses were performed according to Tukey's honest significant difference (HSD) test. For each year, different letters in the same column represent significant differences at $p=0.05$.

At harvest, the incidence and severity of grey mould in the untreated control were $23.89 \%$ and $2.61 \%$ and $16.11 \%$ and $0.91 \%$ in 2018 and 2019 , respectively (Table 3). Both zeolitite-based products showed a statistically significant reduction of grey mould infections both in 2018 and 2019 (Table 3). No significant differences were recorded between the two zeolitites. However, in 2018, vines treated with ICZCu showed a higher but not statistically significant reduction of disease incidence and severity compared to those treated with ICZ. In 2019, the activity of the products was very similar and ensured lower disease incidence and severity levels, not exceeding $5.00 \%$ and $0.08 \%$, respectively (Table 3 ).

In both years of trials, the sour rot incidence and severity in the untreated control $(40.00 \%$ and $3.86 \%$ in 2018 , and $28.33 \%$ and $1.50 \%$ in 2019 ) were higher than those of grey mould (Table 3 ). The applications of the two different zeolitites were also effective against sour rot infections. As for grey mould, the two products showed similar levels of activity, in both years of the trial, with significant differences compared to the untreated control. The incidence of sour rot was $11.11 \%$ and $7.78 \%$ in 2018 and $7.22 \%$ and $4.44 \%$ in 2019 in ICZ and ICZCu, respectively, pointing out a higher but not statistically different activity of ICZCu compared to ICZ (Table 3).

\subsection{Effect of the Zeolitite Residue on Leaf Reflectance and on Grape and Wine Composition}

\subsubsection{Leaf Reflectance}

Leaf reflectance measurements, carried out in the Controguerra vineyard at harvest on 19 September 2019, did not show any differences for both products in the NDVI and GNDVI indices, between vines treated 10 days before the measurement (ICZ-1 and ICZCu-1) and the control 
(Table 4). Conversely, NDVI and GNDVI indices were different compared to the control, when vines were treated 2 days before the measurement (ICZ-2 and ICZCu-2).

Table 4. Leaf reflectance measurements carried out on 19 September 2019 on vines treated with Italian chabasite-rich zeolitite and Italian copper chabasite-rich zeolitite (ICZ and ICZCu).

\begin{tabular}{ccccccc}
\hline & \multicolumn{2}{c}{ Upper Zone Vines } & \multicolumn{2}{c}{ Central Zone Vines } & \multicolumn{2}{c}{ Lower Zone Vines } \\
\hline Treatment & NDVI & GNDVI & NDVI & GNDVI & NDVI & GNDVI \\
\hline 1-ICZ-1 & $0.825 \mathrm{a}$ & $0.513 \mathrm{a}$ & $0.807 \mathrm{a}$ & $0.515 \mathrm{a}$ & $0.822 \mathrm{a}$ & $0.554 \mathrm{a}$ \\
2-ICZCu-1 & $0.813 \mathrm{ab}$ & $0.535 \mathrm{a}$ & $0.809 \mathrm{a}$ & $0.517 \mathrm{a}$ & $0.808 \mathrm{a}$ & $0.517 \mathrm{ab}$ \\
3-ICZ-2 & $0.755 \mathrm{bc}$ & $0.479 \mathrm{ab}$ & $0.756 \mathrm{~b}$ & $0.473 \mathrm{~b}$ & $0.745 \mathrm{~b}$ & $0.460 \mathrm{bc}$ \\
4-ICZCu-2 & $0.728 \mathrm{c}$ & $0.400 \mathrm{~b}$ & $0.736 \mathrm{~b}$ & $0.438 \mathrm{~b}$ & $0.727 \mathrm{~b}$ & $0.427 \mathrm{c}$ \\
5-Control & $0.791 \mathrm{ab}$ & $0.499 \mathrm{a}$ & $0.811 \mathrm{a}$ & $0.518 \mathrm{a}$ & $0.803 \mathrm{a}$ & $0.513 \mathrm{ab}$ \\
\hline
\end{tabular}

ICZ-1 and ICZCu-1 differed for the date of the last application, 9 September, from ICZ-2 and ICZCu-2 that were treated on 17 September. NDVI = Normalized Difference Vegetation Index; GNDVI = Green Normalized Difference Vegetation Index. Statistical analyses were performed according to Tukey's honest significant difference (HSD) test. For each year, different letters in the same column represent significant differences at $p=0.05$.

In particular, significantly lower values of NDVI and GNDVI were found in ICZCu-2, in each of the three vineyard areas, upper, central, and lower, with differences in NDVI of 0.063, 0.075, and 0.076, and in GNDVI of $0.099,0.080$, and 0.086, compared to the untreated control (Table 4). The NDVI and GNDVI indices in ICZ-2 were higher but not statistically different from those of the ICZCu-2 and not always significantly lower than those recorded in the untreated control (Table 4).

\subsubsection{Grape and Wine Composition}

The grapes harvested from ICZ-1 and ICZ-2 treatments did not show any difference compared to the untreated control for any of the assessed parameters: yield per plant, $\mathrm{pH}$, and seed or berry weight. However, soluble solids and total acidity were higher and lower, respectively, but not statistically different compared to the untreated control (Table 5). On the contrary, the grapes coming from ICZCu-1 and ICZCu-2 differed significantly in the level of soluble solids: 21.1 and $20.8^{\circ}$ Brix, respectively, compared to the untreated control, $19.0^{\circ}$ Brix (Table 5).

Table 5. Mean yield and main grape composition parameters recorded on 19 September 2019 at harvest in Trebbiano d'Abruzzo vines of Controguerra vineyard treated with Italian chabasite-rich zeolitite and Italian copper chabasite-rich zeolitite (ICZ and ICZCu).

\begin{tabular}{|c|c|c|c|c|c|c|}
\hline \multirow{2}{*}{ Treatment } & Yield & $\begin{array}{l}\text { Soluble } \\
\text { Solids }\end{array}$ & \multirow[t]{2}{*}{$\mathrm{pH}$} & $\begin{array}{c}\text { Total } \\
\text { Acidity }\end{array}$ & $\begin{array}{c}\text { Grape Seed } \\
\text { Weight }\end{array}$ & $\begin{array}{c}\text { Grape Berry } \\
\text { Weight }\end{array}$ \\
\hline & $\left(\right.$ Kg vine $\left.^{-1}\right)$ & ( ${ }^{\circ}$ Brix $)$ & & $\left(\mathrm{g} \mathrm{L}^{-1}\right)$ & $\left(\mathrm{g} \mathrm{L}^{-1}\right)$ & $\left(\mathrm{g} \mathrm{L}^{-1}\right)$ \\
\hline 1-ICZ-1 & $12.8 \mathrm{a}$ & $20.0 \mathrm{ab}$ & $3.4 \mathrm{a}$ & $5.7 \mathrm{ab}$ & $0.4 \mathrm{a}$ & $2.4 \mathrm{a}$ \\
\hline 2-ICZCu-1 & $12.9 \mathrm{a}$ & $21.1 \mathrm{a}$ & $3.4 \mathrm{a}$ & $5.0 \mathrm{~b}$ & $0.4 \mathrm{a}$ & $2.4 \mathrm{a}$ \\
\hline 3-ICZ-2 & $13.0 \mathrm{a}$ & $19.8 \mathrm{ab}$ & $3.4 \mathrm{a}$ & $5.7 \mathrm{ab}$ & $0.4 \mathrm{a}$ & $2.3 \mathrm{a}$ \\
\hline 4-ICZCu-2 & $12.9 \mathrm{a}$ & $20.8 \mathrm{a}$ & $3.4 \mathrm{a}$ & $5.2 \mathrm{ab}$ & $0.5 \mathrm{a}$ & $2.4 \mathrm{a}$ \\
\hline 5-Control & $12.9 \mathrm{a}$ & $19.0 \mathrm{~b}$ & $3.4 \mathrm{a}$ & $6.0 \mathrm{a}$ & $0.4 \mathrm{a}$ & $2.3 \mathrm{a}$ \\
\hline
\end{tabular}

ICZ-1 and ICZCu-1 differed for the date of the last application, 9 September, from ICZ-2 and ICZCu-2 that were treated on 17 September. Statistical analyses were performed according to Tukey's honest significant difference (HSD) test. For each year, different letters in the same column represent significant differences at $p=0.05$.

The grapes from ICZ-1 and ICZ-2 also showed a soluble solid content lower than that of ICZCu-1 and ICZCu-2 (Table 5). Moreover, total acidity was lower in ICZCu-1 and ICZCu-2 grapes than in ICZ-1 and ICZ-2, and in untreated control grapes (Table 5). The other parameters, yield per plant, pH, and seed or berry weight, did not differ among treatments (Table 5). Moreover, no differences were noticed between ICZ-1 and ICZ-2 and ICZCu-1 and ICZCu-2 (Table 5). 
As for the grapes, the wine from bunches harvested in ICZ-1 and ICZ-2 did not show any statistical differences from the wine of the untreated control. Nevertheless, ethyl alcohol and total acidity contents were higher and lower, respectively, but not statistically different in comparison with the untreated control (Table 6). On the contrary, the wines of ICZCu-1 and ICZCu-2 had significantly higher ethyl alcohol levels of 1.2 and $1.1 \%$ vol. and lower levels of total acidity and malic acid compared to the untreated control (Table 6). ICZCu-1 and ICZCu-2 wine showed higher ethyl alcohol level and lower total acidity and malic acid levels than ICZ-1 and ICZ-2 wines but without any significant difference (Table 6). Residual sugars, $\mathrm{pH}$, volatile acidity, and tartaric acid were not different among treatments (Table 6). As for grapes, no difference was found among the investigated enological parameters between ICZ-1 and ICZ-2, and between ICZCu-1 and ICZCu-2 treatments (Table 6).

Table 6. Chemical composition of the wines obtained from Trebbiano d'Abruzzo vines of Controguerra vineyard treated in 2019 with Italian chabasite-rich zeolitite and Italian copper chabasite-rich zeolitite (ICZ and ICZCu), after eight months of ageing.

\begin{tabular}{|c|c|c|c|c|c|c|c|}
\hline \multirow[t]{2}{*}{ Treatment } & $\begin{array}{c}\text { Ethyl } \\
\text { Alcohol }\end{array}$ & $\begin{array}{c}\text { Residual } \\
\text { Sugars }\end{array}$ & pH & $\begin{array}{c}\text { Total } \\
\text { Acidity }\end{array}$ & $\begin{array}{l}\text { Volatile } \\
\text { Acidity }\end{array}$ & $\begin{array}{c}\text { Malic } \\
\text { Acid }\end{array}$ & $\begin{array}{c}\text { Tartaric } \\
\text { Acid }\end{array}$ \\
\hline & (\% vol.) & $\left(\mathrm{g} \mathrm{L}^{-1}\right)$ & & $\left(\mathrm{g} \mathrm{L}^{-1}\right)$ & $\left(\mathrm{g} \mathrm{L}^{-1}\right)$ & $\left(\mathrm{g} \mathrm{L}^{-1}\right)$ & $\left(\mathrm{g} \mathrm{L}^{-1}\right)$ \\
\hline 1-ICZ-1 & $12.3 \mathrm{ab}$ & $1.2 \mathrm{a}$ & $3.3 \mathrm{a}$ & $5.6 \mathrm{ab}$ & $0.5 \mathrm{a}$ & $1.6 \mathrm{ab}$ & $3.4 \mathrm{a}$ \\
\hline 2-ICZCu-1 & $13.0 \mathrm{a}$ & $1.2 \mathrm{a}$ & $3.3 \mathrm{a}$ & $5.3 \mathrm{~b}$ & $0.5 \mathrm{a}$ & $1.4 \mathrm{~b}$ & $3.2 \mathrm{a}$ \\
\hline 3-ICZ-2 & $12.4 \mathrm{ab}$ & $1.2 \mathrm{a}$ & $3.3 \mathrm{a}$ & $5.5 \mathrm{ab}$ & $0.5 \mathrm{a}$ & $1.6 \mathrm{ab}$ & $3.4 \mathrm{a}$ \\
\hline 4-ICZCu-2 & $12.9 \mathrm{a}$ & $1.1 \mathrm{a}$ & $3.3 \mathrm{a}$ & $5.3 \mathrm{~b}$ & $0.5 \mathrm{a}$ & $1.4 \mathrm{~b}$ & $3.4 \mathrm{a}$ \\
\hline 5-Control & $11.8 \mathrm{~b}$ & $1.3 \mathrm{a}$ & $3.3 \mathrm{a}$ & $5.9 \mathrm{a}$ & $0.5 \mathrm{a}$ & $1.8 \mathrm{a}$ & $3.4 \mathrm{a}$ \\
\hline
\end{tabular}

ICZ-1 and ICZCu-1 differed for the date of the last application, 9 September, from ICZ-2 and ICZCu-2 that were treated on 17 September. Statistical analyses were performed according to Tukey's honest significant difference (HSD) test. For each year, different letters in the same column represent significant differences at $p=0.05$.

\section{Discussion}

The modern approach in the control of pests and disease is based on innovative products and strategies aimed at reducing the impact on the environment, also ensuring human health [24-26]. Thus, this study was carried out in order to assess the activity of two environmentally friendly products based on chabasite-rich zeolitites against grapevine bunch rots.

The application of Italian chabasite-rich zeolitite (ICZ) carried out in the 2018-2019 period on vines of the cv. Trebbiano d'Abruzzo confirmed the efficacy against grey mould and sour rot already observed on Montepulciano and Cococciola grapevine cultivars [5].

Moreover, the most interesting results were obtained with the application of Italian copper chabasite-rich zeolitite (ICZCu), a new formulation, which showed results in some cases that were higher than those obtained with ICZ, and proved effective against downy mildew [27], probably also by the presence of copper in the formulation.

The activity of the two zeolitite products was also notable in severe disease pressure conditions, assessed especially for the sour rot. In the Controguerra vineyard, the incidence and severity of sour rot were higher than those detected for grey mould, in 2018 especially, when, however, both the zeolitite products showed effective control of the infections, significantly reducing yield losses.

The zeolitite applications carried out before rainfall associated with the infection occurrence were confirmed to be an effective strategy in the control of grapevine rots, thanks to the persistence and resistance to wash-off [5]. The layer of mineral particles that form on the treated plant and allows both water absorption [28,29] and formation of physical barrier is the main zeolitite mode of action towards the germination and development of the mycelium of rots [30].

The leaf reflectance measurements on the vines treated with the two different zeolitites did not show any differences compared to the untreated control in the NDVI and GNDVI indices, 10 days after application. The decrease of the two indices assessed two days after application, probably due to the zeolitite deposit on the leaf, was higher in the vines treated with ICZCu than in those treated with ICZ. 
These differences were probably due to the greater presence of fine-size particles (5-10 $\mu)$. In fact, these particles are 70\% in ICZCu whilst in ICZ they do not exceed 50\% [31]. This characteristic probably gives ICZCu greater adhesion, persistence, and better coverage of the leaf surface.

Increases in net photosynthesis on apple trees treated with zeolitites were observed for 15 days after the application [17]. This effect was attributed to the $\mathrm{CO}_{2}$ absorption capacity by zeolitites, which would determine increases of carbon dioxide near the stomata. Therefore, it might not be excluded that the significant increase of grape soluble solids and wine alcohol content in vines treated with ICZCu is attributable to the different presence of fine size particles in the two products. These differences may be associated with different effects on leaf processes; likewise, the presence of copper in ICZCu contributed side activity in reducing grey mould [32,33].

For both zeolitites, the assessment of the effect of residue on the composition of grapes and wines did not show any differences between vines treated 2 or 10 days before harvest. No decrease of the yield quality was noticed. Therefore, the effects of zeolitites were attributable to the applications towards the infections, carried out from pre-flowering, before the expected rainfall. The increase of soluble solids and alcohol content, especially verified for ICZCu, might be associated with a leaf temperature reduction, due to the ability of the zeolitite to reflect the infrared radiation, which improves the water-use efficiency, yield, and fruit quality $[17,34]$.

The possible quality increase of white wines regarding tartaric stability by adding $8 \mathrm{~g}$ of zeolitites $\mathrm{L}^{-1}$ [19] was not observed in the present study. As expected, this lack of an effect was probably due to the low amount of zeolitite residues, even in the case of application two days after sampling, compared to the quantity of zeolite used in the study mentioned above.

\section{Conclusions}

Our results confirmed the ability of zeolitites to reduce the infection of grey mould and sour rot, encouraging their use in organic and integrated viticulture. Moreover, the Italian copper chabasite-rich zeolitite, for its activity towards downy mildew, can be simultaneously and effectively applied against the main grapevine diseases, according to the epidemiological patterns associated with growth stage and rainfall occurrence. Furthermore, the low concentration of copper compared to most copper compounds is in agreement with the current European regulations to reduce the use of copper because of its environmental toxicity.

Finally, the activity against L. botrana infestations [5] further highlighted the potential and versatility of zeolitites in modern pest and disease grapevine control strategies based on the use of low-impact products and a reduced number of applications as well as on the improvement of epidemiological and aetiological knowledge of pathogens [35].

Supplementary Materials: The following are available online at http:/www.mdpi.com/2077-0472/10/12/580/s1, Table S1: Rainfall, temperature and plant wetting in rainy days of Controguerra vineyard in 2018, Table S2: Rainfall, temperature, and plant wetting in rainy days of Controguerra vineyard in 2019.

Author Contributions: Conceptualization, F.C.; methodology, F.C. and L.S.; software, G.P.; validation, F.C., S.D.M. and L.S.; formal analysis, G.P.; investigation, F.C. and L.S.; resources, F.C.; data curation, F.C.; writing-original draft preparation, F.C.; writing - review and editing, F.C. and S.D.M.; visualization, F.C.; supervision, F.C. and S.D.M.; project administration, F.C.; funding acquisition, F.C. All authors have read and agreed to the published version of the manuscript.

Funding: This research was funded by University of Teramo by FARDIB ("Fondo di Finanziamento per Progetti di Ricerca di Ateneo", Fund for University Research Projects), 3/06/2019-30/11/2020.

Acknowledgments: The Authors thank the Camillo Montori Farm, Piane Tronto, Controguerra (TE) for the technical support.

Conflicts of Interest: The authors declare no conflict of interest. The funders had no role in the design of the study; in the collection, analyses, or interpretation of data; in the writing of the manuscript, or in the decision to publish the results. 


\section{References}

1. Johnston, P.R.; Seifert, K.A.; Stone, J.K.; Rossman, A.Y.; Marvanová, L. Recommendations on generic names competing for use in Leotiomycetes (Ascomycota). IMA Fungus 2014, 5, 91-120. [CrossRef] [PubMed]

2. Steel, C.C.; Blackman, J.W.; Schmidtke, L.M. Grapevine Bunch Rots: Impacts on Wine Composition, Quality, and Potential Procedures for the Removal of Wine Faults. J. Agric. Food Chem. 2013, 61, 5189-5206. [CrossRef] [PubMed]

3. Zoecklein, B.W.; Williams, J.M.; Duncan, S.E. Effect of Sour Rot on the Composition of White Riesling (Vitis vinifera L.) Grapes. Small Fruits Rev. 2000, 1, 63-77. [CrossRef]

4. Barata, A.; Gonzãjlez, S.; Malfeito-Ferreira, M.; Querol, A.; Loureiro, V. Sour rot-damaged grapes are sources of wine spoilage yeasts. FEMS Yeast Res. 2008, 8, 1008-1017. [CrossRef]

5. Calzarano, F.; Valentini, G.; Arfelli, G.; Seghetti, L.; Manetta, A.C.; Metruccio, E.G.; Di Marco, S. Activity of Italian natural chabasite-rich zeolitites against grey mould, sour rot and grapevine moth, and effects on grape and wine composition. Phytopathol. Mediterr. 2019, 58, 307-321. [CrossRef]

6. Hall, M.E.; Loeb, G.M.; Wilcox, W.F. Control of Sour Rot via Chemical and Canopy Management Techniques. Am. J. Enol. Vitic. 2018, 69, 342-350. [CrossRef]

7. Marois, J.J.; Nelson, J.K.; Morrison, J.C.; Lile, L.S.; Bledsoe, A.M. The influence of berry contact within grape clusters on the development of Botrytis cinerea and epicuticolar wax. Am. J. Enol. Vitic. 1986, 37, $293-296$.

8. Barata, A.; Santos, S.C.; Malfeito-Ferreira, M.; Loureiro, V. New Insights into the Ecological Interaction Between Grape Berry Microorganisms and Drosophila Flies During the Development of Sour Rot. Microb. Ecol. 2012, 64, 416-430. [CrossRef]

9. Vogel, A.R.; White, R.S.; MacAllister, C.; Hickey, C.C. Fruit Zone Leaf Removal Timing and Extent Alters Bunch Rot, Primary Fruit Composition, and Crop Yield in Georgia-grown 'Chardonnay' (Vitis vinifera L.). HortScience 2020, 55, 1654-1661. [CrossRef]

10. Vanderweide, J.; Frioni, T.; Ma, Z.; Stoll, M.; Poni, S.; Sabbatini, P. Early Leaf Removal as a Strategy to Improve Ripening and Lower Cluster Rot in Cool Climate (Vitis vinifera L.) Pinot Grigio. Am. J. Enol. Vitic. 2019, 71, 70-79. [CrossRef]

11. Passaglia, E.; Sheppard, R.A. The Crystal Chemistry of Zeolites. Natural Zeolites 2001, 45, 69-116. [CrossRef]

12. Jha, B.; Singh, D.N. Fly Ash Zeolites; Springer Science and Business Media LLC: Berlin, Germany, 2016; Volume 78, p. 211.

13. Bish, D.L.; Ming, D.W. Natural Zeolites: Occurrence, Properties, Application; Mineralogical Society of America: Chantilly, VA, USA, 2001; p. 654.

14. Eroglu, N. A review: Insecticidal potential of Zeolite (Clinoptilolite), toxicity ratings and general properties of Turkish Zeolites. In Proceedings of the 11th International Working Conference on Stored Product Protection, Chiang Mai, Thailand, 24-28 November 2014; pp. 755-767.

15. Malekian, R.; Abedi-Koupai, J.; Eslamian, S.S. Influences of clinoptilolite and surfactant-modified clinoptilolite zeolite on nitrate leaching and plant growth. J. Hazard. Mater. 2011, 185, 970-976. [CrossRef]

16. Nakhli, S.A.A.; Delkash, M.; Bakhshayesh, B.E.; Kazemian, H. Application of Zeolites for Sustainable Agriculture: A Review on Water and Nutrient Retention. Water Air Soil Pollut. 2017, 228, 464. [CrossRef]

17. De Smedt, C.; Steppe, K.; Spanoghe, P. Beneficial effects of zeolites on plant photosynthesis. Adv. Mater. Sci. 2017, 2, 1-11. [CrossRef]

18. De Smedt, C.; Someus, E.; Spanoghe, P. Potential and actual uses of zeolites in crop protection. Pest Manag. Sci. 2015, 71, 1355-1367. [CrossRef]

19. Mercurio, M.; Bish, D.L.; Cappelletti, P.; De Gennaro, B.; Grifa, C.; Izzo, F.; Morra, V.; Langella, A. The combined use of steam-treated bentonites and natural zeolites in the oenological refining process. Miner. Mag. 2016, 80, 347-362. [CrossRef]

20. Malferrari, D.; Laurora, A.; Brigatti, M.F.; Coltorti, M.; Di Giuseppe, D.; Faccini, B.; Passaglia, E.; Vezzalini, M.G. Open-field experimentation of an innovative and integrated zeolitite cycle: Project definition and material characterization. Rendiconti Lince 2013, 24, 141-150. [CrossRef]

21. Rouse, J.W.; Haas, R.H.; Schell, J.A.; Deering, D.W. Monitoring Vegetation Systems in the Great Plains with Erts, In Third Earth Resources Technology Satellite-1 Symposium. Volume I: Technical Presentations, Nasa SP-351; Freden, S.C., Mercanti, E.P., Becker, M., Eds.; NASA: Washington, DC, USA, 1974; pp. 309-317. 
22. Gitelson, A.A.; Kaufman, Y.J.; Merzlyak, M.N. Use of a green channel in remote sensing of global vegetation from EOS-MODIS. Remote Sens. Environ. 1996, 58, 289-298. [CrossRef]

23. AA.VV. Methods of Community Analysis to Use in Wine Sector. In Official Gazette of the European Communities, 3 October 1990, No. 2676/90; Commission Regulation (EEC): Brussels, Belgium, 1990.

24. Di Marco, S.; Osti, F.; Bossio, D.; Nocentini, M.; Cinelli, T.; Calzarano, F.; Mugnai, L. Electrolyzed acid water: A clean technology active on fungal vascular pathogens in grapevine nurseries. Crop. Prot. 2019, 119, 88-96. [CrossRef]

25. Calzarano, F.; Stagnari, F.; D’Egidio, S.; Pagnani, G.; Galieni, A.; Di Marco, S.; Metruccio, E.G.; Pisante, M. Durum Wheat Quality, Yield and Sanitary Status under Conservation Agriculture. Agriculture 2018, 8, 140. [CrossRef]

26. Parrilli, M.; Sommaggio, D.; Tassini, C.; Di Marco, S.; Osti, F.; Ferrari, R.; Metruccio, E.; Masetti, A.; Burgio, G. The role of Trichoderma spp. and silica gel in plant defence mechanisms and insect response in vineyard. Bull. EÈntomol. Res. 2019, 109, 771-780. [CrossRef] [PubMed]

27. Calzarano, F.; University of Teramo, Teramo, Italy. Personal Communication, 2020.

28. Glenn, D.M.; Puterka, G.J. Particle Films: A New Technology for Agriculture. Hortic. Rev. 2010, 31, 1-44. [CrossRef]

29. Tatlier, M.; Munz, G.; Henninger, S.K. Relation of water adsorption capacities of zeolites with their structural properties. Micropor. Mesopor. Mater. 2018, 264, 70-75. [CrossRef]

30. Walters, D.R. Disguising the Leaf Surface: The Use of Leaf Coatings for Plant Disease Control. Eur. J. Plant. Pathol. 2006, 114, 255-260. [CrossRef]

31. Agrisana, S.R.L.; Latina, Italy. Personal communication, 2020.

32. Gullino, M.L.; Morando, A. Copper compounds: Old products, still very effective in modern viticulture. Vignevini 1984, 11, 35-37.

33. Aleksić, G.; Milićević, Z.; Kuzmanović, S.; Starović, M.; Stevanović, M.; Delibašić, G.; Živković, S. Efficacy of copper citrate in grapevine disease control. Pestic. Fitomed. 2019, 34, 103-109. [CrossRef]

34. Conde, A.; Pimentel, D.; Neves, A.; Dinis, L.-T.; Bernardo, S.; Correia, C.M.; Gerós, H.; Moutinho-Pereira, J. Kaolin Foliar Application Has a Stimulatory Effect on Phenylpropanoid and Flavonoid Pathways in Grape Berries. Front. Plant. Sci. 2016, 7, 1150. [CrossRef]

35. Baránek, M.; Armengol, J.; Holleinová, V.; Pečenka, J.; Calzarano, F.; Peňázová, E.; Vachůn, M.; Eichmeier, A. Incidence of symptoms and fungal pathogens associated with grapevine trunk diseases in Czech vineyards: First example from a north-eastern European grape-growing region. Phytopathol. Mediterr. 2018, 57, 449-458. [CrossRef]

Publisher's Note: MDPI stays neutral with regard to jurisdictional claims in published maps and institutional affiliations.

(C) 2020 by the authors. Licensee MDPI, Basel, Switzerland. This article is an open access article distributed under the terms and conditions of the Creative Commons Attribution (CC BY) license (http://creativecommons.org/licenses/by/4.0/). 